\title{
Passive Transfer of Anti-Dirofilaria immitis Hemagglutinating Antibody from the Mother Dog to its Offspring
}

\author{
Mineo HAYASAKI \\ Department of Veterinary Medicine, Faculty of Agriculture, \\ Tokyo University of Agriculture and Technology, \\ 3-5-8 Saiwaicho, Fuchu, Tokyo 183
}

(Received 11 November 1981/Accepted 25 June 1982)

\begin{abstract}
Twenty mother dogs, and their 19 fetuses and 57 newborn puppies were examined by the indirect hemagglutination (IHA) test for the transfer of anti-Dirofilaria immitis antibody from mothers to their offspring. The antibody was shown to be passively transferred via colostrum to the puppies and to persist in the puppies for approximately two months. On the other hand, no antibody was detected in the fetuses even when their mothers had high titers. The time-course studies indicated that, on the day of parturition, the colostral IHA titer was identical with that of the maternal serum and also that, within the first 5 to 7 days, the titers of maternal sera rapidly declined and then gradually decreased until 48 days after parturition.
\end{abstract}

In a previous paper [7], the author reported that some puppies having never spent the potentially infective season had a specific antibody to Dirofilaria immitis in the circulation, when assessed by the indirect hemagglutination (IHA) test using the intrauterine microfilarial antigen. For instance, a puppy had a comparatively high titer of 1:1024, suggesting a possible acquisition of $D$. immitis-specific antibody from its dam.

No information, however, is available on the kinetics of transfer of the helminthspecific antibody from mother dogs to their offspring. In rats and pigs, several investigators $[3,6,10,11,13]$ have reported the immunity of infants to parasitic infections acquired through maternal colostrum, but the kinetics of these anti-parasitic antibody transfer has not been surveyed.

The purpose of the present study was to find whether $D$. immitis-specific antibody could be transferred from mothers to their offspring and also to reveal the route and kinetics of the antibody transfer in dogs.

\section{MATERIALS AND METHODS}

Dog serum and colostrum: Twenty mother dogs, their 9 fetuses obtained by caesarean section at later stages (more than 50 days) of gestation and their 57 newborn puppies were employed. All animals were bled; the serum was separated and stored at $-40^{\circ} \mathrm{C}$ until use. The blood from the newborn puppy was obtained by ear vein puncture. Colostrum was drawn by hand from the teats of lactating dams and centrifuged at 3,000 rpm for $15 \mathrm{~min}$. The top fat layer was discarded and the intermediate layer of colostrum was used.

Indirect hemagglutination (IHA) test: The IHA test using the intrauterine microfilarial antigen, was performed by the method previously described [7].

Gel filtration: Gel filtration was conducted as described by Zvaifler and Becker [16]. A column of $2.5 \times 90 \mathrm{~cm}$ was packed with Sephadex G-200 equilibrated with PBS ( $\mathrm{pH} 7.2$ ). Fractions of $5 \mathrm{ml}$ were collected at a flow rate of $10 \mathrm{~m} l$ per hr. Protein profiles were determined by measuring OD at $280 \mathrm{~nm}$.

Treatment with 2-mercaptoethanol (2-ME): The samples of IHA-positive colostrum were treated with 2-ME as previously described [8]. 
Table 1. Serum IHA titers in mother dogs, their fetuses and neonates

\begin{tabular}{|c|c|c|c|c|c|}
\hline \multicolumn{3}{|c|}{ Dam } & \multicolumn{3}{|r|}{ Offspring } \\
\hline \multirow{2}{*}{ No. } & \multicolumn{2}{|c|}{ IHA titer } & \multirow{2}{*}{$\begin{array}{l}\text { Growth } \\
\text { Stage }\end{array}$} & \multirow{2}{*}{$\begin{array}{l}\text { Number of } \\
\text { cases } \\
\text { examined }\end{array}$} & \multirow{2}{*}{ Age in days*/IHA titer } \\
\hline & Serum & Colostrum & & & \\
\hline 1 & $<8$ & $<8$ & $\mathrm{~N}$ & 6 & $3 /<8 ;<8 ;<8 ;<8 ;<8 ;<8$ \\
\hline 2 & $<8$ & $<8$ & & ND & ND \\
\hline 3 & $<8$ & $<8$ & $N$ & 4 & $2 /<8 ;<8 ;<8 ;<8$ \\
\hline 4 & $<8$ & ND & $N$ & 1 & $2 /<8$ \\
\hline 5 & $<8$ & $<8$ & & ND & ND \\
\hline 6 & 8 & $<8$ & $N$ & 4 & $12 /<8,19 /<8,28 /<8 ;<8$ \\
\hline 7 & 8 & $<8$ & N & 5 & $7 /<8 ;<8 ;<8 ;<8 ; 8$ \\
\hline 8 & 8 & 16 & $N$ & 3 & $10 /<8 ;<8 ;<8$ \\
\hline 9 & 1024 & ND & $\mathrm{N}$ & 5 & $2 / 128 ; 128 ; 512 ; 1024 ; 2048$ \\
\hline 10 & 2048 & 2048 & $N$ & 3 & $33 / 64 ; 128 ; 256$ \\
\hline 11 & 8192 & ND & $N$ & 5 & $2 / 512 ; 1024,8 / 256 ; 512 ; 512$ \\
\hline 12 & 8192 & ND & N & 4 & $7 / 1024,14 / 64,21 / 64,28 / 16$ \\
\hline 13 & 16384 & 16384 & $N$ & 1 & $10 / 1024$ \\
\hline 14 & ND & ND & $N$ & 6 & $45 / 8 ; 16 ; 16 ; 16 ; 16 ; 16$ \\
\hline 15 & 8 & ND & $F$ & 6 & $<8_{i}<8_{i}<8_{i}<8_{i}<8_{i}<8$ \\
\hline 16 & 32 & ND & $\mathrm{F}$ & 4 & $<8 ;<8 ;<8 ;<8$ \\
\hline 17 & 64 & ND & $\mathrm{F}$ & 3 & $<8 ;<8 ;<8$ \\
\hline 18 & 512 & ND & $\mathrm{F}$ & 6 & $<8 ;<8 ;<8 ;<8 ;<8 ;<8$ \\
\hline
\end{tabular}

\section{RESULTS}

The IHA titers of the serum and the colostrum samples collected on the day of parturition from mother dogs infected with D. immitis and the serum samples collected from the fetuses and suckling neonates in various days after birth are given in Table 1. When mothers (dogs Nos. 1-8) showed a very low antibody titer of 1:8 or less in both serum and colostrum, their newborn puppies showed similar serum titers. On the other hand, when mothers (dogs Nos. 9-14) showed high IHA titers, their suckling puppies exhibited high titers, but usually lower than those of their mothers. As seen in dogs Nos. 11 and 12, the antibody of the puppies seems to reduce in titers with age after parturition. The IHA titer of the colostrum on the day of parturition was identical with that of the serum (Table
1). In contrast, no antibody was detected in the fetuses, even if their mothers had high antibody titers.

Sephadex G-200 gel filtration of the serum from a neonate, a fetus and their mothers (dogs Nos. 11 and 16) revealed that the maximum IHA activity of the serum from the neonate and the mother was recovered in the second peak ( $\operatorname{IgG}$ ), while no IHA activity was found in any peak of the fetal serum (Fig. 1).

The protein concentration of the second peak of the fetal serum was much lower than that of the neonate (Fig. 1-D).

Two litters from mother dogs Nos. 19 and 20 were divided into two groups just after birth for determining the transfer route of the IHA antibody. As shown in Table 2, no IHA antibody was detected in the puppies reared on artificial milk (Esbilac ${ }^{\circledR}$, Borden chemical, Inc., Norfolk, 


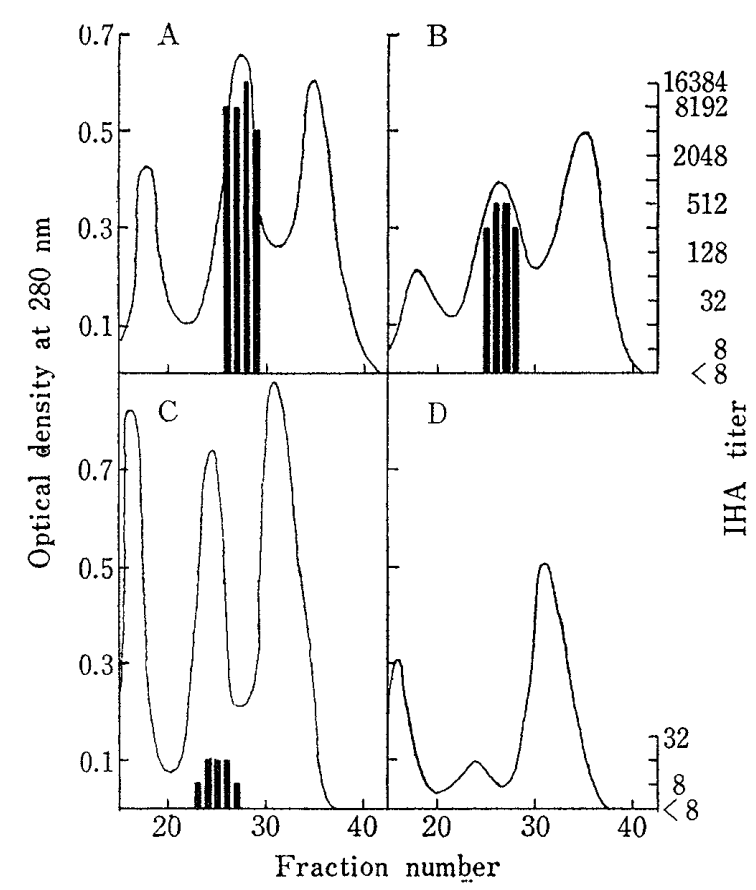

Fig. 1. Sephadex G-200 gel filtration profiles and IHA activities of sera obtained from two mothers, a puppy and a fetus.

A : Dam No. 11. B: 2-day-old puppy from dam No. 11.

C: Dam No. 16. D: Fetus from dam No. 16 at later stage of gestation. IHA: Indirect hemagglutination.

Va) for 2 days after birth, while the antibody was detected in the remaining puppies suckled by their mothers for 2 or 7 days after birth. Unexpectedly, four puppies showed IHA activity higher (1:1281:512) than their mothers. This may have been due to the fact that they were suckled

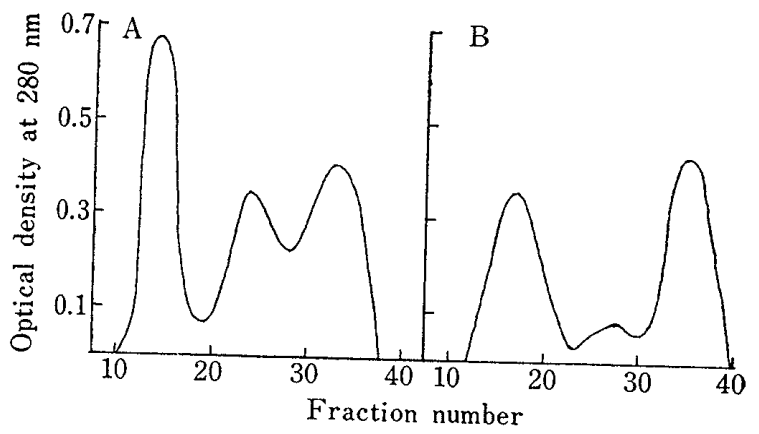

Fig. 2. Sephadex G-200 gel filtration profiles of sera obtained from the puppies reared on either colostrum or artificial milk.

A : Puppy reared on colostrum. B: Puppy reared on artificial milk.

not only by their mother (dog No. 19 with an IHA titer of 1:64) but also by a fostermother (dog No. 13 with an IHA titer of $1: 16,384)$, since these two dams were housed in the same animal room and one delivered three days later than the other. Gel filtration indicated that the profile of the serum obtained from the artificial milk-reared puppy differred from that of the colostrumsucking puppy in the protein contents of the second protein peak, and is very similar to that of the fetal serum, as shown in Figs. 1 and 2.

Three dams were monitored for the time-course changes of colostral IHA activity (Fig. 3). The colostral IHA activities rapidly declined within the first 5 to 7 days and then gradually decreased until the

Table 2. IHA titers in two litters fed with either colostrum or artificial milk

\begin{tabular}{|c|c|c|c|c|c|c|}
\hline \multicolumn{3}{|c|}{ Dam } & \multicolumn{4}{|c|}{ Offspring } \\
\hline \multirow{2}{*}{ No. } & \multicolumn{2}{|c|}{ IHA titer } & \multirow{2}{*}{$\begin{array}{l}\text { Days } \\
\text { after } \\
\text { birth }\end{array}$} & \multirow{2}{*}{ Fed with } & \multirow{2}{*}{$\begin{array}{l}\text { Number of } \\
\text { cases } \\
\text { examined }\end{array}$} & \multirow{2}{*}{ Serum IHA titer } \\
\hline & Serum & Colostrum & & & & \\
\hline \multirow[t]{2}{*}{19} & 64 & 64 & 7 & Colostrum & $4^{*}$ & $128 ; 256 ; 256 ; 512$ \\
\hline & & & 2 & Artificial milk & 2 & $<8 ;<8$ \\
\hline \multirow[t]{2}{*}{20} & 32 & ND & 2 & Colostrum & 3 & $32 ; 32 ; 32$ \\
\hline & & & 2 & Artificial milk & 1 & $<8$ \\
\hline
\end{tabular}

* Puppies were suckled by their mother and a foster-mother(dog No. 13 with titer of $1: 16,384)$ as well.

IHA, ND: See the foot-notes on Table 1. 


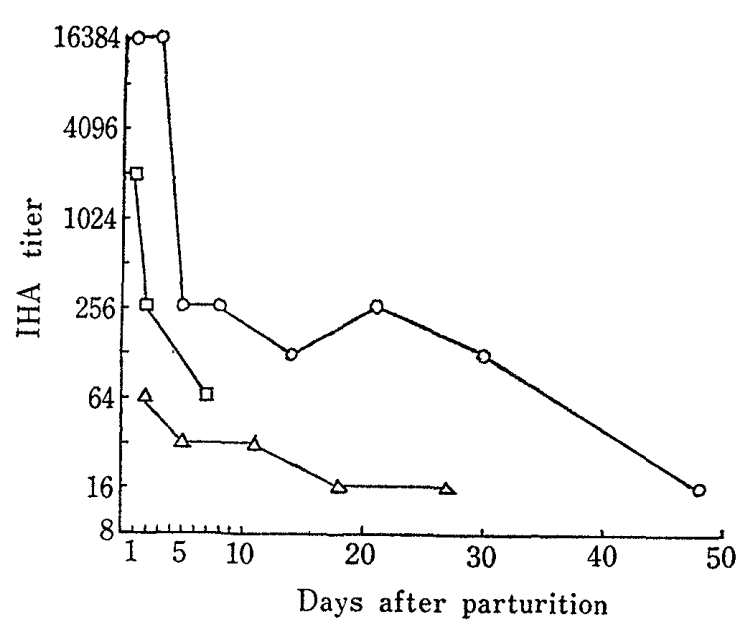

Fig. 3. The time-course changes of IHA activity in the colostrum and the milk collected from dams after parturition.

IHA : Indirect hemagglutination. $\square \longrightarrow \square$ : Dam No.

10. $O-O$ : Dam No. 13.

$\triangle \longrightarrow \triangle$ : Dam No. 19.

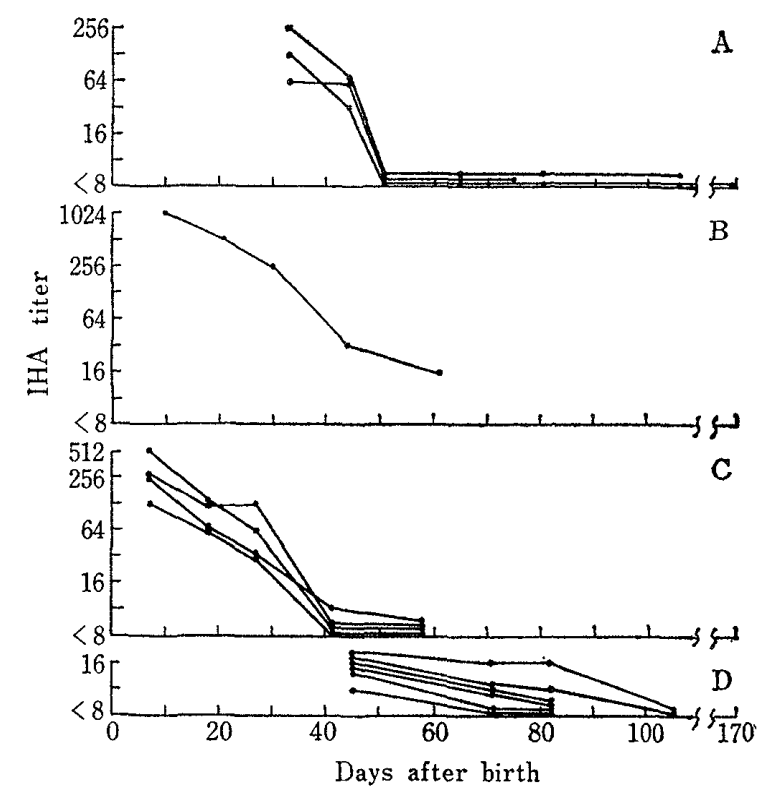

Fig. 4. The time-course changes of serum IHA activity of fourteen puppies of four litters.

A: Puppies from dam No. 10. B: A puppy from dam No. 13. C: Puppies from dam No. 19. D: Puppies from dam No. 14. IHA: Indirect hemagglutination.

48th day of the observation, except for the slight increase in the IHA titer (from 1:125 to $1: 256$ ) in $\operatorname{dog}$ No. 13 on the 21 st day after parturition.

The 2-ME treatment of the colostrum was attempted to find if 2-ME-sensitive antibody (IgM) was associated with the IHA activity. It indicated little participation of IgM antibody in colostral IHA activity (data not shown).

The kinetics of serum IHA activity in newborn puppies is shown in Fig. 4. Between the 41st and 61st days after birth, IHA activities in newborn puppies were depressed to $1: 16$ or less. Thereafter, no substantial IHA activity was detected until the 170th day of the observation, in all puppies except two, both of which maintained the minimum levels of IHA titer until the 82nd day (Fig. 4).

\section{DISCUSSION}

In mammals, the mechanism of antibody transmission is generally classified into three according to the route; they are the transplacental route as seen in human, the transcolostral route as seen in horses and cattle, and the intermediate type of these two groups as seen in dogs and cats [1]. The present results demonstrated that the canine hemagglutinating antibody specific to $D$. immitis could be passively transferred from mother dogs to their offspring via colostrum, and that it persisted in the puppies for approximately two months. This conclusion may be supported by such facts as the appearance of high serum IHA activities in the sucking neonates, the lack of serum IHA activity in both the fetuses and neonates reared on artificial milk, the extremely low protein concentration of the second peak (IgG) of the serum gel filtration profiles of the fetuses and artificial milk-reared newborn puppies, and the higher antibody levels of the serum IHA titer in four puppies suckled by the fostermother than those in their mothers (Table 2). These data clearly indicate that the colostral antibody transfer is the main 
route in dogs.

The kinetics of IHA titer in the colostrum and the milk after parturition in the present study is very similar to the observations by other investigators $[9,12,15]$ on IgG levels in canine colostrum and milk. For instance, Heddle and Rowley [9] reported that the percentage of colostral IgG rapidly decreased from about $80 \%$ on the day of parturition to below $20 \%$ on the 5 th day and such a low level persisted for approximately one month in contrast with the conversed elevation of IgA.

Gillette and Filkins [5] reported that the absorption of orally administrated antibodies by the newborn puppies became maximum about $8 \mathrm{hr}$ after birth, and ceased in $24 \mathrm{hr}$. In contrast, other investigators $[1,2]$ reported that the absorption of the colostral antibody through the gut lasted for about 10 to 12 days after birth. The present study demonstrated that the serum IHA activities in newborn puppies persisted for 44 days, when the titer decreased to 1:32. Such a distinct difference in antibody persistence between newborn puppies fed the hyperimmune serum and those fed colostrum could have possibly been due to the difference in the intestinal absorption of serum and colostral antibodies. The reason for such different absorption is still unknown.

The present study failed to demonstrate the transfer of the hemagglutinating antibody across the placenta. Similar lack of transplacental transfer of canine antibody has previously been demonstrated by Tomoda [14], who failed to detect the presence of the gamma fraction electrophoretically in fetal dogs or newborn puppies before suckled. Gillette and Filkins [5] also failed to detect anti-Salmonella pullorum antibody in any of the puppies delivered from the bitches that had been intrave- nously given the hyperimmune serum. Some investigators $[1,4]$ have reported the transplacental transfer of small amounts of antibodies. Even if the transplacental transfer of the antibody occurred in the puppies in our study, it seems that the amount of the antibody transferred was not so large as to be detected by the IHA test. The test has been shown to be sensitive enough to detect serum anti-D. immitis antibody in infected dogs [7].

The results of this work may aid better understanding of the mechanism of passive immunity in dogs and provide a possible explanation for false positive serological reaction in non-infected puppies. Finally, further investigations are required to elucidate the immunological role of the transferred antibody in the protective immunity against $D$. immitis infection in puppies.

ACKNOWLEDGEMENTS. The author wishes to express his gratitude to Emeritus Professor S. Kume and Professor I. Ohishi, Tokyo University of Agriculture and Technology, for their constant guidance in the course of this study.

\section{REFERENCES}

[1] Brambell, F. W. R. (1958). The passive immunity of the young mammal. Biol. Rev. Cambridge Phil. Soc. 33, 488-531.

[2] Engle, R. L., and Woods, K. R. (1960). Comparative biochemistry and embryology. In The plasma proteins, vol. II, Putnam, F. W., editor, Academic Press, New York, 183-265.

[3] Gemmel, M. A., Blundell-Hasell, S. K., and Macnamara, F. N. (1969). Immunological responses of the mammalian host against tapeworm infections. IX. The transfer via colostrum of immunity to Taenia hydatigena. Exp. Parasitol. 26, 52-57.

[4] Gillespie, J. H., Baker, J. A., Burgher, J., Robson, D., and Gilman, B. (1957). The immune response of dogs to distemper virus. Conell Vet. 48, 103-126.

[5] Gillette, D. D., and Filkins, M. (1966). Factors affecting antibody transfer in the newborn puppy. Am. J. Physiol. 210, 419-422.

[6] Greenberg, Z. (1971). Passive transfer of im- 
munity to $N$. brasiliensis (Travassos, 1914) from mother rats to offspring. J. Parasitol. 57, $685-687$.

[7] Hayasaki, M. (1981). Indirect hemagglutination test for diagnosis of canine filariasis. Jpn. J. Vet. Sci. 43, 21-26.

[8] Hayasaki, M. (1982). Reaginic and hemagglutinating antibody production in dogs infected with Dirofilaria immitis. Jpn. J. Vet. Sci. 44, 63-70.

[9] Heddle, R. J., and Rowley, D. (1975). Dog immunoglobulins. I. Immunological characterization of dog serum, parotid saliva, colostrum, milk and small bowel fluid. Immunology 29, 185-195.

[10] Jones, V. E., and Ogilvie, B. M. (1967). Reaginic antibodies and immunity to Nippostrongylus brasiliensis in the rat. III. Passive immunity in the young rat. Int. Arch. Allergy 31, 490-504.

[11] Kelly, G. W., and Nayak, D. P. (1965). Passive immunity to Ascaris suum transferred in colostrum from sows to their offspring. $A m$. J. Vet. Res. 26, 948-950.

[12] Reynolds, H. Y., and Johnson, J. S. (1970). Quantitation of canine immunoglobulins. $J$. Immunol. 105, 698-703.

[13] Terry, R. J. (1955). Transmission of antimalarial immunity (Plasmodium berghei) from mother rats to their babies during lactation. Trans. R. Soc. Trop. Med. Hyg. 49, 302.

[14] Tomoda, I. (1963). Paper electrophoretic studies on serum proteins in domestic animals. II. Normal value and physiological variations of serum proteins in dogs. Jpn. J. Vet. Sci. $\mathbf{2 5}$, 5-19. (in Japanese with English summary).

[15] Vaerman, J-P., and Heremans, J. F. (1969). The immunoglobulins of the dog. II. The immunoglobulins of canine secretions. Immunochemistry 6, 779-786.

[16] Zvaifler, N. J., and Becker, E. L. (1966). Rabbit anaphylactic antibody. J. Exp. Med. 123, 935950.

犬糸状虫特異血球凝集抗体の母子間移行について：早崎窂夫（東京農工大学家畜内科学教室）- 20 頭の母犬とその胎仔 19 頭および新生仔 57 頭について, 犬糸状虫特異抗体の母子間移行を間接赤血球凝

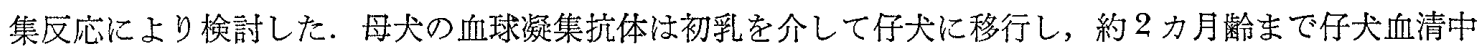
に検出された。 しかし，母犬が高い抗体価を示しても，その胎仔からは抗体は検出されなかった。出産 当日の乳汁の抗体価は血清抗体価と同值を示したが，出産後 5〜7 日までに抗体価は急激に低下し，さ らに観察終了時の出産後 48 日までは徐々に低下した. 